\title{
CODEMIXING IN AN ENTERTAINMENT TV SHOW: HOW WHICH IS FUNCTIONS IN INDONESIANS'REPERTOIRE
}

\author{
Suhandoko ${ }^{\bowtie}$, Widatul Hasanah, Cindy Nuriana, Maulana Rahman Firdaus, Jabal Maula, \\ Favian Reswara Sani \\ English Department, Faculty of Arts and Humanities, UIN Sunan Ampel Surabaya, Jl. A. Yani 117 Surabaya \\ \handoko07f@gmail.com
}

\begin{abstract}
The present article portrays the use of "which is" as a currently popular mixedcode among Indonesians, especially teenagers and public figures, since the 2010s or popularly named as the language of South-Jakartans (Bahasa Anak Jaksel) by taking an Indonesian TV show as the data collection sites. The data were the comments of one of the judges of Indonesian Idol 2018, named ME. For investigation purpose, videos containing the "which is" phrase uttered by ME were sorted, transcribed, and analyzed. The analysis focused on how "which is"functions in the utterances. It was found that remarkable functions of "which is"include as substituting conjunctions and discourse markers. The substituting conjunctions include cause-effect and coordinating conjunctions, as for the discourse markers likely function to minimize face-threatening act.
\end{abstract}

Keywords: codemixing; which is; functions

DOI: $10.15642 / N O B E L .2019 .10 .1 .32-51$

The discussions of codeswitching (CS), codemixing (CM), and lexical borrowing (LB) have been significant since Weinrich's Languages in Contact was published in 1979. Since then, numerous linguistic scholars have been intrigued to make CS, CM, and LB as the main object of their study. Among them are Pfaff (1979) who proposes a set of questions to help us make a distinction between CS and LB: the existence of L1 equivalence, the use of L2 words in the community, the speaker's knowledge of the L1 equivalence, and how speaker views the L2 words in his repertoire. Different from Pfaff who suggests guiding questions, Poplack (1980) and Gumperz (1982) outlines the guidelines to make a clear distinction between CS and LB followed by Myers-Scotton's (1992) Matrix Language Frame Model. In addition to the distinction between CS and LB, others also propose demarcations to distinguish CS from CM. McLaughlin (1984) defines CM "to refer to switches within sentences" and CS "to refer to changing language over phrases or sentences."

Nowadays, not only does CM involve interactions in dailylife, it has been an important part of the genre of art and entertainment such as films, soap operas, news, and got-talent program. The use of $\mathrm{CM}$ in entertainment is apprently claimed to be an effective way of 
communication in conveying messages to the viewer, stimulating them to memorize the ads, therefore serve the purpose (Mushtaq \& Zahra, 2012) and potentially attract the readers' attention (Kia \& Yee, 2011). Kia and Yee aver that people with good command of English often code-mix English into their local language, not only in conversation but also in entertainment programs.

Countless studies have made CM, CS, and LB, especially those exist in entertainments such as films, songs, magazine, social media and TV programs as their focuses. Those studies examined them from the viewpoints of forms, locations, patterns, and functions. Rohardiyanto (2017) studied the frequency of mixed-codes in a magazine for teens as well as investigated the factors underlying its use. He found that mixed-codes in teenagers' writing portray their desire to show off their social class, to attract the attention of others, to make communication easier and more efficient, and to make an enjoyable situation and a closed relationship among others. Different from Mulyajati (2018) who examined the types of CM along with its syntactical unit in words, phrases, and clauses in a talk show in an Indonesian TV, Ali, Malik, \& Jillani (2019) studied code-mixing in Indian songs. They found that the songwriters use $\mathrm{CM}$ in the lyrics due to the external factor in which they need to "satiate the needs of pleasure seeking and pleasure-loving audience."

However, Chairat's (2014) investigation on the use of CM in Thai songs revealed that it is less preferred by both adolescent and middle age groups reasoning that it indicates inconsistencies in the message conveyed in the songs. However, instead of perceiving CM as a disruption of the message in the song, Pradina, Soeriasoemantri, \&Heriyanto (2013) aver that it is not merely to change the language but further they perceive it as a politeness strategy. Holmes (2008) points out that in order to minimize face-threatening acts, the lexicon of another language is sometimes carefully used.

Furthermore, Kasoema \& Amri (2016) examined CM in radio broadcasting. Not only do they analyze the types of $\mathrm{CM}$, they further analyze its functions. Of the four reasons, the study seems to suggest that stylistic reasons dominate the use of CM acts. Very little data indicate it functions to accentuate personal and social identity as was found by Luciana (2006).

As a part of the linguistic phenomenon, CM is nowadays not only used by the middleup class, even now from low social class especially teenagers. The Jakarta Post in 2018 reported that currently Indonesian teenagers extensively put CM in their language repertoire. People call this phenomenon of CM as Bahasa Anak Jaksel (South Jakartans Language). 
Among the mixed-codes is the which is phrase among other words such as literally, prefer, and many others.

In English grammar, which is a relative pronoun that modifies non-human subject or object in relative clauses. In Indonesian teenagers' slang, which is combined with copula is to add stylistic nuance to suit them with the most common words in Indonesian or Malay, di mana and yang mana. When compared to yang mana or di mana which consists of three syllables, which inserted in Indonesian sentences or utterances will be less appealing. Its meaning will also be potentially misunderstood or missed since it only consists of one syllable. In order to accentuate its existence as a mixed-code and to give more aesthetical nuance, Indonesian speakers combine which and is. Instead of using yang mana and di mana which sound“oldies”, which is is more acceptable among teenagers.

In English grammar, complex sentences are connected with subordinate conjunctions. However, Indonesian grammar does not recognize the use of di mana or yang mana (equivalent terms for Wh-complementizer who, whom, which, and where) as prepositions like $d i$, ke, dari, or pada. The use of di mana and yang mana as conjunctions frequently happens in Indo-European to the Indonesian or Malay translation. Principally, the Indonesian and Malay grammar only recognize yang as a conjunction to connect complex sentences as shown in the following example

Eng : The bike which I bought yesterday was broken

Ind $\quad$ : Sepeda yang mana saya beli kemarin sudah rusak $\mathbf{x}$

Ind $\quad$ : Sepeda yang kemarin saya beli sudah rusak.

Consequently, the use of "yang mana" and "di mana" as conjunctions should be discouraged due to its failure to satisfy the standardized grammar that they can only be used in question sentences (Chee, 2010).

Despite the fact that numerous studies have been conducted in attempt to analyze how yang mana and di mana function in sentences and utterances, no one to the best of my knowledge has studied which is as the main focus especially on how it functions in sentence or utterance wherein such phrase is previously mentioned as a viral phenomenon among the Indonesians. Therefore, this paper calls into question "How does which is function in Indonesians' repertoire?" 


\section{REVIEW OF LITERATURE}

\section{Bilingualism and Identity}

Language is not merely conveying ideas and a system of communication between people. It is also a social phenomenon that exists in society. Language builds social relationships and social interactions, equally, build language;thus, when learning a language, we are also bound to people or society or culture. In the study of linguistics, this is known as sociolinguistics. Simply, sociolinguistics refers to the study of language in relation to human and society. As a social and cultural phenomenon (Trudgil, 1971), studying how language relates to society in order to understand "the structure of language and of how languages function in communication" is crucial (Wardhaugh, 2006). Hence, the ability to speak in two languages (bilinguals) portrays not only one's linguistics behavior but also personal and sociocultural being.

In general, bilingualism is categorized into simultaneous and sequential or successive bilingualism. Tabors (2008) states that when a person (typically a child) receives exposure to both L1 and L2 from birth in their home environment concurrently, they will acquire two languages simultaneously or usually referred to as simultaneous bilingualism. Meanwhile, those exposed to only their native language at home and then to foreign language i.e. upon entering school will experience the successive bilingualism. In addition to this bilingualism classification, Valdez and Figueora (1994) categorize bilinguals into elective and circumstantial bilinguals based on the reasons why L2 is acquired. When bilinguals acquire L2 in a formal setting where L2 is an additional course at school, they are categorized as elective bilinguals. On the other hand, those who acquire L2 because they are required to do so to attend school or to find work they are categorized as circumstantial bilinguals or more often named as substantive bilinguals because their L1 skills tend to decrease or loss in preference to the dominant language used in the environment, L2.

As a product of a culture, language functions not only as a tool for communication, but also as "a symbolic system with the power to create and shape symbolic realities, such as values, perceptions, and most importantly identities through discourse" (Kramsch, 2003). Therefore, language is a part of identity, not only as personal but also as social identity. Consequently, a bilingual person belongs to different cultures that reflect different identities. Moreover, bilinguals were revealed to be more willing to deal with cultural diversity, to resolve opposition and disagreements (Brannen \& Thomas, 2010). 


\section{Code Switching, Code Mixing, and Lexical Borrowing}

According to Gardner-Chloros (2009), CS is the process of moving back and forth between two languages or dialects or registers of the same language. CS comprises many types which Hoffmann (2014) divides them into inter-sentential, intra-sentential, tag switching and establishing continuity with the previous speakers. CM which occurs from sentence to sentence is called inter-sentential and the other which occurs within a sentence is called intrasentential. Tag switching involves a tag, an exclamation, or a parenthetical remark in a different language, for example, the use of I mean, you know, right?. As for the establishing continuity with the previous speakers, the motive is to confirm each other between interlocutors due to a triggering effect.

Different from LB when terms or words from its matrix language translated into another language will potentially change the meaning and therefore result in communication disruption, CM occurs in either word or phrase level that not only because of the inexistence of equivalent terms in matrix language, it further occurs because of some reasons such as to attract audiences' attention, to create impressions to people, or to avoid expressing embarrassing topic (Leung \& Chan, 2016).

\section{"Yang Mana", "Di Mana", and "Which Is"}

A language is frequently influenced by foreign languages that it frequently borrows words from them. A borrowed word is likely translated into local language to suit the local taste buds such as upload in English is translated into unggah in Bahasa Indonesia, gadget in English is translated as gawai in Bahasa Indonesia and so on.

However, there is also words will be too awkward when translated into local language due to the inexistence of equivalent terms, for example, the word computer which refers to a machine that performs processes, calculations, and operations based on certain instructions by software and hardware program is translated into mesin penghitung in Indonesian because compute means menghitung (to compute). Hence, borrowing takes place through the adjustment of phonological and morphological aspect in the borrowed language such as komputer. Other example of LB are case is translated as kes in Malaysian, garage is translated as garasi in Indonesian and many other borrowings. One of the LB phenomena of foreign languages which later then translated into the base or local language to suit the local taste buds is the use of relative phrase who, which, whom, where and when that are translated into yang mana or di mana. 
The widespread use of yang mana and di mana among Indonesians and Malays have caught linguists' attention to investigate whether the phrases have satisfied both grammars. Gani and Aziz (2007) found that di mana and yang mana in Malay are used extensively as conjunctions in relative clauses. However, both Indonesian and Malay standardized grammar do not categorize them as what Gani and Aziz reported. In Indonesian standardized grammar (Tata Bahasa Baku Bahasa Indonesia), yang mana and di mana are not categorized as conjunctions, both intra-sententially, and inter-sententially. Instead, they can only be used in questions (Ramlan, 1983). Likewise, Karim et al. (2008, pp. 251) state that linguistic scholars have listed "dan, atau, tetapi, serta, lalu, malahan, sambil, kemudian, yang, bahwa, untuk, kerana, agar, supaya, kendatipun, jika, apabila and seumpamanya" as conjunctions in their grammar book excluding yang mana and di mana.

Even so, many Indonesian and Malay texts still use yang mana and dimana as conjunctions as Wijana (2006), Chee (2010) and Widiatmoko (2015) found in their studies. Wijana's (2006) analysis on the use of yang mana and dimana in students' writing is not merely functioned as question words, but also as copula, relative clause marker, interclausal and intersentential conjunctions, and other markers which are difficult to identify because they do not have any equivalent in English. A similar finding was also reported by Chee (2010) that provides a final remark on the inappropriateness of yang mana and di mana toward Kamus Dewan (Malay standardized grammar). In a critical response to this, Widiatmoko (2015) urges the importance of the "teaching of standard Indonesian grammar."

Recently a new phrase as an alternative to yang mana and di mana has been viral among social media users especially when South-Jakartan teenagers use it along with other mixed-codes, such as literally, prefer, and I mean. This phrase has been viral since it was circulating on Twitter as jokes indicating the distinctive way the people of South Jakarta talk. An example of this fuss on the Twitter is as tweeted by @iyajgybg, “[...] padinya ditumbuk which is bijinya lepas gitu nah moreafter dikumpulin deh itu hence masi ada kulitnya its fine baru abis itu ditumbuk2 like biar jadi beras literally — petani Jaksel".

\section{METHOD}

In order to investigate how which is functions in Indonesian speakers' repertoire, especially teenagers and public figures, I documented the which is phrase in their utterances. There could be millions of utterances I could have possibly obtained because the phrase is now widely used in social media, radio broadcasting, entertainment program, even in daily interactions. However, in this study, I only focused on documenting which is in an 
entertainment TV show named Indonesian Idol 2018 as a sample because among of the speakers involved in the program, there is one, in this case is the judge named ME, frequently inserts which is in her comments.

In order to investigate the use of which is inserted in ME's comments in Indonesian Idol 2018, I collected all video recordings which were then sorted to find the ones containing which is phrase in ME's comments. During 2018 also called as the ninth season, Indonesian Idol has presented five grand episodes namely: Audition, Elimination, Showcase, Top 15, and Spectacular Show (Top 12). The focus of data collection in this study was the Spectacular Show presenting 13 episodes with 123 performance videos of all contestants (all videos can be accessed in Official Youtube Channel of Indonesian Idol 2018). After watching carefully to all videos and listening to ME's comments on the contestants' performances, I found 9 occurrences in eight episodes on which ME mentioned which is. These nine occurrences were transcribed and analyzed to look into their functions in ME's utterances.

The use of which is in ME's comments was analyzed descriptively by looking into its functions in the sentences in accord with Indonesian grammar. Alternative equivalent words or phrases were sought to substitute which is phrase without leaving its contexts in the utterances, and by so doing the function of which is can be revealed.

\section{RESULTS AND DISCUSSIONS}

\section{Results of the study}

Before discussing how which is functions as slang in Indonesias' repertoire, I present the nine occurrences on which ME mentioned it in her comment.

1) Kan kamu kadang-kadang vokalnya [indistinct]. Di lagu ini sangat pas dikeluarin teknik seperti itu tapi di lagu slow kamu mengurangi teknik yang terlalu berlebihan itu dan itu masuk, which is kamu sudah tahu bagaimana nyanyi di lagu slow, nyanyi di lagu blues, nyanyi di lagu yang dance kamu sudah tahu tekniknya. (ME's comment on Ayu's performance in Spectacular Show Top 11 in the minute of 4:56)

2) Lagu ini tuh bener bener yang pakai hati perasaan which is sebenarnya lagu ini bisa lebih pelan lebih syahdu, lebih indah, tapi setelah diulang lagi Ayu berhasil menyanyikan dengan merontokkan hati saya ini yang beku. (ME's comment on Ayu's performance in Spectacular Show Top 8 in the minute of 5:45) 
3) Sebenarnya kamu tuh sangat memberi warna karakter yang berbeda diantara penyanyipenyanyi yang lain which is itu bagus sekali. (ME's comment on Ayu's performance in Spectacular Show Top 12 in the minute of 6:25)

4) Karena kamu ini nanti akan terjun kemasyarakat which is..terjun ke pasar which is kamu tidak akan bernyanyi lagu dengan genre yang sama terus seperti ini atau karakter vocal yang sama seperti ini terus. Kamu akan ditantang dengan lagu slow. (ME's comment on Ayu's performance in Spectacular Show Top 12 in the minute of 7:56)

5) Mandy Moore itu punya, dia bernyanyi dari umur 4 tahun dia ikut di Disney, Walt Disney kemudian dia halus sekali seperti kaти kamu kembangkan suara-suara kamu yang halus, indah, dan bisa mengenakkan lagu which is kamu di lagu-lagu kover kamu bisa mengenakkan lagu. (ME's comment on Jodie's performance in Spectacular Show Top 8 in the minute of $6: 27$ )

6) Karena ini lagunya Britney Spears di video klipnya dia super seksi dan dia koreografernya dipikirin, yaa Marion masih harus usaha kesananya which is kamu masih harus usaha seperti penyanyiaslinya yang benerbenerluarbiasakoreografernyamateng. (ME's comment on Marion's performance in Spectacular Show Top 7 in the minute of 6:27)

7) Maria itu kemarin-kemarin sering menggunakan baju hitam which is, maaf mohon maaf, kamu berkulit hitam mestinya jangan pakai baju hitam. (ME's comment on Maria's performance in Spectacular Show Top 6 in the minute of 5:52)

8) Kalau misalnya netizen boleh komentar begini, yaah Marion kok nggak ada perkembangan, gitu lagi gitu lagi. Nggak ada melebar kemana-mana lagi which is kamu udah mencoba kemarin itu minggu lalu dengan lagu yang bukan genre kamu, ya kan? (ME's comment on Marion's performance in Spectacular Show Top 10 in the minute of $5: 35)$

9) Joan, kamu mendapatkan empat standing ovation ya which is itu bagus banget. (ME's comment on Joan's performance in Spectacular Show Top 10 in the minute of 3:28)

\section{"Which is" functions as substituting conjunctions}

In the following video transcriptions, it is portrayed how which is function as substituting conjunctions.

A Mandy Moore itu punya..., dia bernyanyi dari umur 4 tahun dia ikut di Disney, MandyMoore has she sing since age 4 years she join in Disney 
Walt Disney kemudian dia halus sekali seperti kamu. Kamu kembangkan

Walt Disney then she smooth very like you You improve

suara-suara kamu yang halus, indah, dan bisa mengenakkan lagu which is

voice your that soft beautiful and can pleasant song which is

kamu di lagu-lagu kover kamu bisa mengenakkan lagu.

you in songs cover you can apleasant song

The free translation of the excerpt in A is as follow:

Mandy More has (unclear), she has sung for Disney since she was four years old because she has a beautiful voice like you. You (must) keep improving your charming voice and (make) the song more pleasant to listen to which is your voice is suitable with cover songs.

In A, ME appreciated one of the female contestants that she has a beautiful voice. ME then encouraged her to improve her singing skills. From excerpt A, it can be seen that the utterance before and after the which is phrase has a cause-effect relationship in that ME encouraged the contestant to improve her soft and beautiful voice because her voice is very suitable with cover songs. For this reason, which is in A can be substituted with cause-effect conjunction such as because or since, hence the sentence can be restated as follow:

Kamu kembangkan suara-suara kamu yang halus, indah, dan bisa mengenakkan lagu karena kamu di lagu-lagu kover kamu bisa mengenakkan lagu.

You (must) keep improving your charming voice and (make) the song more pleasant to listen to because your voice is suitable with cover songs.

Similar to A, "which is" also functions as cause-effect conjunction in B.

B Kalau misalnya netizen boleh komentar begini. Yaah Marion kok

if for example netizens may comment like this Oh dear Marion

nggak ada perkembangan, gitu lagi gitu lagi. Nggak ada melebar kemana-mana no there improvement like that again like that again no there improve everywhere

lagi which is kamu udah mencoba kemarin itu minggu lalu dengan lagu yang again which is you already try previous days that week ago with song that

bukan genre kamu, ya kan?

not genre of yours right? 
The free translation of the excerpt in B is as follow:

If netizens may comment (on your performance this evening), (they would say) $\mathrm{O}$ dear! Why Marion's singing voice is not improving? You don't give new touch in your singing which is you have already tried that (another genre of the song) last week and it is not the genre of the song you always sing.

It can be seen in B that ME expressed her dissatisfaction on one of the female contestants' performance because she did not improve her singing skills. From the excerpt, it appears that the sentence after which is (you have already tried that) becomes the cause of ME's dissatisfaction on the contestant's performance. Therefore, which is in B functions as substituting cause-effect conjunction and, for this reason, which is in B can be restated as follow:

Kalau misalnya netizen boleh komentar begini. Yaah Marion kok nggak ada perkembangan, gitu lagi gitu lagi. Nggak ada melebar kemana-mana lagi karena kamu udah mencoba kemarin itu minggu lalu dengan lagu yang bukan genre kamu, ya kan?

If netizens may comment (on your performance this evening), (they would say) $\mathrm{O}$ dear! Why Marion's singing voice is not improving? You don't give new touch in your singing because you have already tried that (another genre of the song) last week and it is not the song genre you always sing.

Based on the analysis in A and B, we can see that which is in those excerpt functions as cause-effect conjunctions in Indonesian sentences. As mentioned previously, Indonesian grammar does not recognize the use of yang mana and di mana as translated from the English relative pronouns which, who, whom, where, and when. Instead of using yang mana and di mana, there are many alternative words to substitute them, one of them is by using appropriate conjunctions.

In addition to the function as substituting conjunctions in a sentence, I also found that which is might also function as the repetition of cause-effect conjunction which should be avoided due to its inefficiency. The following excerpt explains how which is functions in the utterances.

C Karena kamu nanti akan terjun ke masyarakat which is.. terjun ke pasar because- you- later- will- perform-in-public- which is- perform-in-market 
which is kamu tidak akan bernyanyi lagu dengan genre yang sama terus

which is- you- not- will- sing- song-with- genre- that- same- over and over

seperti ini atau karakter vocal yang sama seperti ini terus. Kamu akan

like- this-or- character- vocal- that- same- like- this-over and over. You- will

ditantang dengan lagu slow.

be challenged-with- song- slow

The free translation of the excerpt in $\mathrm{C}$ is as follow:

Because you are going to perform on stage, which is you are not expected not to sing the same genre of certain songs or the same vocal characters over and over like this.

The utterance in $\mathrm{C}$ shows that ME commented on one of the female candidates' performance. ME suggested that the candidate not sing the songs of the same genre and with the same vocal character. ME added that the contestant is demanded to present the best on her stage performance if she does not want to be left by her admirers or fans. For this reason, which is in $\mathrm{C}$ means a consequence and can be substituted with the conjunction of thus, therefore, hence, and other cause-effect conjunctions. Therefore, the utterance in $\mathrm{C}$ can be restated as follow:

Karena kamu ini nanti akan terjun ke masyarakat which is.. terjun ke pasar maka kamu tidak akan bernyanyi lagu dengan genre yang sama terus seperti ini atau karakter vocal yang sama seperti ini terus. Kamu akan ditantang dengan lagu slow

Since you are going to perform on stage, therefore you are not expected to not sing the same genre of certain songs or the same vocal characters over and over like this.

However, using thus/ therefore/ hence and because/ since/ as in the same sentence is impossible due to redundancy problem. For this reason, which is in $\mathrm{C}$ is actually impractical despite the fact that it means a consequence and, therefore, $\mathrm{C}$ can be restated as follow:

Since you are going to perform on stage, you are not expected to not sing the same genre of certain songs or the same vocal characters over and over like this.

or

You are going to perform on stage; thus, you are not expected to sing the same genre of certain songs or the same vocal characters over and over like this. 
Besides functioning as a substitute for cause-effect conjunction, which is in the following excerpts also functions as substitute for coordinative conjunction which functions to combine two equivalent clauses. The excerpt in D and E explain the phenomenon.

\section{D : Joan, kamu mendapatkan empat standing ovation ya which is itu bagus banget. Joan, you get four standing ovationswhich is that good very}

The free translation of the excerpt in D is as follow:

Joan, you've just earned four standing ovations which is it is very good.

In $\mathrm{D}$, there are two clauses that both are independent yet related to each other because the pronoun "itu/ it/ that" refers to "empat (four) standing ovation(s)". Thus, which is in D can be substituted by and that means to suggest a kind of "comment" on the previous statement. Therefore, "which is" can be substituted with coordinating conjunctions and as stated below:

Joan, kamu mendapat empat standing ovation dan itu bagus banget.

Joan, you've just earned four standing ovations (from the judges), and it is very good.

Similar to D, in the following excerpt, which is also functions as substituting coordinating conjunction.

E Sebenarnya kamu tuh sangat memberi warna karakter yang berbeda diantara

actually you really give color character that different among

penyanyi-penyanyi yang lain which is itu bagus sekali

singer other which is that good very

The free translation of the excerpt in $\mathrm{E}$ is as follow:

Actually, among other singers, your voice character is unique (different) which is it is very good.

In $\mathrm{E}, \mathrm{ME}$ commented on the performance of one of the female contestants that she is blessed with a beautiful voice that distinguishes her from any other singers. In the middle of her comments, ME inserted which is before continuing her comments that contestant's voice character is very good. From this explanation, it can be seen both sentences before and after which is contain all the information necessary to be a complete sentence and therefore both of them are independent clauses. When a sentence contains two independent clauses, they can be joined by using a semicolon or by using a comma followed by a conjunction such as for, and, nor, but, or, and yet. In the case of $\mathrm{E}$, the sentence can be joined by coordinating 
conjunction and because the sentence after which is seems to be an additional information. Based on this explanation, E can be restated as follow:

Actually, among other singers, your voice character is unique (different), and it is very good.

\section{"Which is" functions as discourse markers}

Apart from the findings stating that which is functions to substitute conjunctions, in the following excerpts, which is was found to function as to explain, clarify, and intensify what speakers have said. Sometimes when speakers speak spontaneously, they are aware of saying the considered inappropriate statements; therefore, it is often that they explain, clarify, intensify even change what they have uttered. As we talk, we sometimes insert phrases or expressions to show to the listeners that we need to rephrase, change, clarify, or repeat what we are saying. Pragmatically speaking, these phrases are called discourse markers.

\section{F Kan kamu kadang-kadang vokalnya [indistinctive]. Di lagu ini sangat pas right you sometimes vocal in song this very suitable dikeluarin teknik seperti itu tapi di lagu slow kamu mengurangi teknik sung technique like that but in song slow you reduce technique yang terlalu berlebihan itu dan itu masuk. Which is kamu sudah tahu that undue that and it tune in which is you already know bagaimana nyanyi di lagu slow, nyanyi di lagu blues, nyanyi di how sing in song slow sing in song blues sing in lagu yang dance kamu sudah tahu tekniknya. ... song that dance you already know the technique}

The free translation of the excerpt in $\mathrm{F}$ is as follow:

You frequently use [indistinctive] voice. It is actually appropriate that you use that type of voice in this song but in the slow version you managed to reduce that undue technique and it really tunes in which is you already know when to use a certain type of singing technique in a slow song, blues song, and dance songs.

In F, ME complimented one of the female contestants because she managed to sing a song with a slow, smooth, and charming voice. ME stated that the contestant usually sings with her "a-bit-rocky" voice, but in that evening she managed to reduce her a-bit-rocky voice while singing a slow song which is in ME's opinion is tuning in. ME then repeated the 
compliments and explained the statement about the contestant's ability in singing a slow song with a slow charming voice instead of her usual a-bit-rocky voice. From this explanation, it can be stated that ME made an adjustment of her previous statementto show that a better explanation of what she has just said is about to follow. Sometimes people speak faster than his thinking that they often make mistakes in their statements especially when they do not plan their talks. When someone speaks spontaneously, it is more likely that adjustment is made.

Based on the explanation above, it seems obvious that which is functions to indicate that speakers want to explain their considered inappropriate statements. People sometimes insert phrases or expressions to show that they are about to explain their previous statement with a better one. For this reason, people sometimes use discourse marker such as I mean, what I mean is, in other words, the thing is, you know what I mean, or you know. Based on this explanation, the statement in $\mathrm{F}$ can be restated as follows:

Kan kamu kadang-kadang vokalnya [indistinctive]. Di lagu ini sangat pas dikeluarin teknik seperti itu tapi di lagu slow kamu mengurangi teknik yang terlalu berlebihan itu dan itu masuk. Maksud saya adalah bahwa kamu sudah tahu bagaimana nyanyi di lagu slow, nyanyi di lagu blues, nyanyi di lagu yang dance kamu sudah tahu tekniknya

You frequently use [indistinctive] voice. It is actually appropriate that you use that type of voice in this song but in the slow version you managed to reduce that undue technique and it really tunes in. In other words, you already know when to use a certain type of singing technique in a slow song, blues song, and dance songs.

Similar to F, which is in the following excerpt also functions as a discourse marker.

G Karena ini lagunya Britney Spears di video klipnya dia super seksi dan dia Because this song of Britney Spears in video clip her she super sexy and she koreografernya dipikirin, yaa Ma masih harus usaha ke sananya choreography her well-thought well Ma still has to work hard to reach there which is kamu masih harus usaha seperti penyanyi aslinya yang bener-bener which is you still have to work like singer original who really luar biasa koreografernya mateng. amazing choreography her well-thought

The free translation of the excerpt in $\mathrm{G}$ is as follow: 
Since this song is sung by Britney Spears which she was so sexy and her choreography is very good, you still have to work hard which is you have to work hard to present the song as good as the original singer that her choreography is amazing.

In G, ME commented on one of the female contestants who sang Britney Spears' song. ME explained that Britney Spears always sings beautifully with mind-blowing choreographies and demanded that the contestant work harder to perform as good as Britney. In the middle of her comment, ME inserted which is followed by additional comments which means almost the same as the previous comments. ME advised the contestant to work harder in singing the song, with the choreography all at once, so as to be as good as the original singer. From this explanation, it can be inferred that which is likely functions as a discourse marker which indicates that a speaker needs to expand upon what she previously said to be more appropriate and comprehensible for the listeners. Almost similar to F, which is in $\mathrm{G}$ also functions as a discourse marker prior to the explanation of what has been previously said. Therefore, $\mathrm{G}$ can be restated as follow:

Karena ini lagunya Britney Spears di video kilpnya dia super seksi dan dia koreografernya dipikirin, yaa Marion masih harus usaha ke sananya artinya bahwa kamu masih harus usaha seprti penyanyi aslinya yang bener-bener luar biasa koreografernya mateng.

Since this song is sung by Britney Spears which she was so sexy and her choreography is very good, you still have to reach that, I mean you have to work hard to sing the song as good as the original singer that her choreography is amazing.

Slightly different from $\mathrm{F}$ and $\mathrm{G}$ in that which is functions as discourse marker indicating that speakers are explaining what they has previously said, which is in $\mathrm{H}$ also functions as discourse marker indicating speakers are intensifying what the speakers have previously said.

H Lagu ini tuh bener bener yang pakai hati perasaan which is sebenarnya lagu ini song this really that use heart feeling which is actually song this

bisa lebih pelan, lebih syahdu, lebih indah, tapi setelah diulang lagi Ay can more slow more calm more beautiful but after COP-repeat again Ay

berhasil menyanyikan dengan merontokkan hati saya ini yang beku.

manage sing with melt heart my this that frozen 
The free translation of the excerpt in $\mathrm{H}$ is as follow:

This song should be sung with the heart which is this song can actually be sung more slowly, calmly and beautifully. But after you sing it one more time, you managed to sing it and it melts my frozen heart.

In $\mathrm{H}, \mathrm{ME}$ commented on the performance of one of the female contestants that she should sing the slow songs with heart. In the middle of her comments, ME inserted which is followed by the statement that the song can actually be sung more slowly, calmly, and beautifully. It seems that ME tried to intensify her statement about sing with heart is singing the song more slowly calmly, and beautifully. Based on this explanation, it can be inferred that which is functions as the marker that speakers are intensifying what has been previously said. It is often when speakers need to intensify their statement they insert I mean or the kinds before the intensifier statements. Therefore, the utterance in $\mathrm{G}$ can be restated as follows:

Lagu ini tuh bener bener yang pakai hati perasaan maksud saya sebenarnya lagu ini bisa lebih pelan lebih syahdu, lebih indah, tapi setelah di ulang lagi Ayu berhasil menyanyikan dengan merontokkan hati saya ini yang beku

This song should be sung with heart I mean this song can actually be sung more slowly, calmly, and beautifully. But after you sing it one more time, you managed to sing it and it melts my frozen heart.

As a type of discourse marker, I mean also indicates about positive politeness wherein a certain situation someone does not feel good in expressing their opinion due to the fear of insulting their interlocutors, they tend to do face-saving act to lower the tension of their sayings. It is here too that which is functions as face-saving act as shown by the following excerpt.

I Maria itu kemarin-kemarin sering menggunakan baju hitam which is,
Maria black dress which is
in the previous performances often wear maaf banget, kamu berkulit hitam mestinya jangan pakai baju hitam.
I'm sorry very you've got black skin should have not wear black dress

The free translation of the utterance in I is as follows:

In the previous performance, you wore a black dress which is, I'm sorry to say this, you have got black skin. You should have not worn the black dress. 
In I, ME commented on one of the female contestants because she often wears black clothes in her performance. In the middle of her comment, ME inserted which is followed by the additional comments that she clarified about the contestant's preference on black dresses in her performances. ME clarified that because she has got black skin, she should not have worn black or dark dresses. The contestant should have worn brighter clothes. At this stage which is functions as a marker that speakers want to clarify their previous statement. Based on this explanation, I can be restated as follow:

\section{Maria itu kemarin-kemarin sering menggunakan baju hitam maksud saya mohon maaf banget, kamu berkulit hitam mestinya jangan pakai baju hitam.}

In the previous performance, you (Ma) wore a black dress I mean, I'm sorry to say this, you have got black skin. You should have not worn the black dress.

From the analysis of the excerpt F, G, H, and I, it can be assumed that which is, in addition to functioning as substituting conjunctions, also function as discourse markers which not only functions to intensify, clarify, and to revise speakers' statement, but also as a politeness strategy to minimize face-threatening act.

\section{Discussions}

The findings of the present study on how which is functions in sentences or utterances, more or less, echo what Chee (2011), Widiatmoko, (2015) and Wijana (2006) found in their studies that di mana and yang mana as the translation of Wh-complementizer (who, which, when, where) functions as conjunctions. However, considering that both yang mana and di mana do not accord the standardized grammar in Indonesia and Malay language; therefore, instead of addressing and categorizing them as conjunctions as stated by Sundusiah (2014), which is, yang mana, and di mana function as substituting conjunctions.

The use of which is among Indonesian especially teenagers nowadays cannot be judged as the indication of their unconfidence toward their Indonesian or local language, instead, it indicates their eagerness to show off their social class (Rohardiyanto, 2017). This is considering that which is is popular among teenagers in South Jakarta of Indonesia in which an area occupied mostly by middle-up class society. Moreover, it indicates awareness of their attempts to avoid using yang mana and di mana which do not correspond to standardized Indonesian grammar. We admit that there is no attempt to use appropriate language in 
standardized Indonesian grammar, for example, using proper conjunctions or words to replace which is; still, we need to appreciate their use of which is instead of bully or discourage them.

Another finding related to the function of which is as discourse markers in ME's comments is its significance use as politeness strategies in conversation. Resonating Pradina, Soeriasoemantri, \&Heriyanto (2013) who opine that CM may minimize face-threatening act, Dumanig, Lumayag, \& David (2015) suggest that in order to "achieve approval" of requests or suggestions, using other languages (mixing the codes) can be an alternative.In her comments, there were circumstances in which ME was exposed to the conditions that demand her to intensify, revise, or merely to soften her comments on the contestants. This, quoting Janney (2017), indicates ME's skills in involving different linguistic systems to modify meanings "at different levels of linguistic organization" or known as having linguistic avoidance competence.

\section{CONCLUSION}

This study examined how which is functions in Indonesia by focusing on the analysis of ME's comments in Indonesian Idol 2018 as a CM phenomenon. The findings of this study highlight that which is functions as substituting conjunctions and as politeness strategies. As a result of a pop culture which is currently booming, the use of which is among Indonesian teenagers and public figures should not be resolutely responded. Along with the criticisms and people's disfavor on the use of which is in conversation, people will slowly put it out of their repertoire. However, efforts to grow and develop people's understanding to use good and appropriate Indonesian should be emphasized especially in the teaching of standardized Indonesian and the exposure of standardized Indonesian through mass media such as newspaper, TV news, formal events like seminars and conference. This will at least provide a balance to the phenomena of the CM among citizens.

\section{REFERENCES}

Ali, M. M., Malik, N. A., \& Jillani, S. F. (2019). Acritical analysis of intra sentenial codemixing in Indian. Science International,28(2), 2119-2127.

Brannen, M. Y., \& Thomas, D. C. (2010). Bicultural individuals in cross cultural management - implications and opportunity. International Journal of Cross Cultural Management. https://doi.org/10.1177/1470595809359580

Chairat, P. (2014). English code-mixing and code-switching in Thai songs. NIDA Journal of Language and Communication, 19(22), 1-29. https://doi.org/10.1016/S0146- 


\section{3(12)00004-8}

Chee, L. K. (2010). Yang mana sebagai kata hubung: Analisis linguistik korpus. 297-320.

Dumanig, F. P., Lumayag, L., \& David, M. K. (2015). Code switching in mixed couples' interaction: A conversation analysis. Protagonist International Journal of Management And Technology ( PIJMT ), 2(1), 1-10.

Gardner-Chloros, P. (2009). Code-switching. Cambridge: Cambridge University Press.

Gumperz, J. J. (1982). Discourse Strategies. Cambridge: Cambridge University Press.

Hoffmann, C. (2014). Introduction to Bilingualism. New York: Routledge.

Holmes, J. (2008). An Introduction to Sociolinguistics. Harlow, England: Pearson Longman.

Janney, R. W. (2017). The whole truth and nothing but the truth: Linguistic avoidance in the O . J . Simpson transcripts. In W. Falkner \& H. J. Schmid (Eds.), Words, lexemes, concepts - approaches to the lexicon. Studies in honour of Leonhard Lipka. London: ARNDT, Horst.

Karim, N.S., Onn, F.M., Musa, H.H., and Mahmood, A.H. (2008). Tatabahasa Dewan. Edisi Ketiga. Kuala Lumpur: Dewan Bahasa dan Pustaka.

Kasoema, A. R., \& Amri, Z. (2016). Code mixing used by radiobroadcaster of Pesona FM on radio program of song request. E-Journal of English Language \& Literature, 5(1).

Kia, L. S., \& Yee, T. K. (2011). Code-mixing of English in the entertainment news of Chinese newspapers in Malaysia.International Journal of English Linguistics, 1(1), 314.

Kramsch, C. (2003). In search of the intercultural. Journal of Sociolinguistics. 6 (2), 275-282. https://doi.org/10.1111/1467-9481.00188

Leung, C. H., \& Chan, Y. (2016). Sociolinguistic phenomenon of code mixing in Hong Kong: From a perspective of marketing communications. Humanities \& Social Sciences Reviews, 4(1), 20-26. https://doi.org/10.18510/hssr.2016.413

Luciana, L. (2006). Code-switching in Indonesian radio and television programs: Linguistic and sociolinguistic perspectives. Asian Englishes, 9(1), 4-23. https://doi.org/10.1080/13488678.2006.10801174

McLaughlin, B. (1984). Child psychology. Second-language acquisition in childhood: Preschool children (2nd ed.). Hillsdale, NJ, US: Lawrence Erlbaum Associates, Inc.

Mulyajati, E. (2018). The Indonesian-English code-mixing in Just Alvin show at Metro tv. Journal of English Language and Culture, 7(2), 57-63. https://doi.org/10.30813/jelc.v7i2.1024

Mushtaq, H., \& Zahra, T. (2012). An analysis of code-mixing in television commercials. Language In India, 12(February), 565-577.

Myers-Scotton, C. (1992). Comparing codeswitching and borrowing. Journal of Multilingual and Multicultural Development, 13(1-2), 19-39. https://doi.org/10.1080/01434632.1992.9994481

Pfaff, C. W. (1979). Constraints on language mixing: Intrasentential code-switching and borrowing in Spanish/English. Language, 55(2), 291. https://doi.org/10.2307/412586

Poplack, S. (1980). Sometimes I'll start a sentence in Englishy termino en español : Toward a typology of code-switching 1. Linguistics, 18, 581-618. 
https://doi.org/10.1515/ling.1980.18.7-8.581

Pradina, F. A., Soeriasoemantri, Y., \&Heriyanto. (2013). Code-switching as the positive politeness strategies in Indonesian 4 th grade students ' conversation. Research on Humanities and Social Sciences, 3(22), 19-25.

Ramlan, M. (1983). Ilmu Bahasa Indonesia: Sintaksis. Yogyakarta: UB Karyono.

Rohardiyanto, I. (2017). The occurrence of code mixing in Indonesian girl magazine kawanku. Buana Gender, 2(1). https://doi.org/10.22515/bg.v2i1.802

Sundusiah, S. (2014). Perbandingan klausa inti dan klausa sematan bahasa Indonesia dan

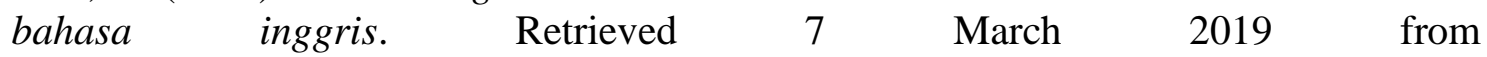
http://file.upi.edu/Direktori/FPBS/JUR._PEND._BHS._DAN_SASTRA_INDONESIA/ SUCI_SUNDUSIAH/artikel_ilmiah/perbandingan_klausa_Indo-Inggris.pdf.

Tabors, P. O. (2008). One child, two languages: A guide for preschool educators of children learning English as a second language. Baltimore: MD: Paul H. Brookes Publishing Co.

Trudgil, P. (1971). The Social Differentiation of English in Norwich. Cambridge: Cambridge University Press.

Wardhaugh, R. (2006). An Introduction to Sociolinguistics. Oxford: Blackwell Publishing.

Widiatmoko, B. (2015). Pemakaian di mana dan yang mana sebagai kata hubung dalam kalimat bahasa Indonesia. Jurnal Pujangga, 1(22), 65-74.

Wijana, I. D. P. (2006). Pemakaian kata di mana dalam tulisan mahasiswa. Humaniora, $18(3), 254-262$. 